\title{
Structure and properties of sintered corrosion-resistant steel manufactured from electroerosive powders
}

\author{
E. V. Ageev, Dr. Eng., Associate Prof., Dept. "Technology of materials and transport”, Head of Scientific Education \\ Center "Powder metallurgy and functional coatings"', e-mail: ageev_ev@mail.ru \\ E. V. Ageeva, Cand. Eng., Associate Prof., Dept. "Technology of materials and transport”, e-mail: ageeva-ev@yandex.ru \\ S.V. Khardikov, Cand. Eng., Engineer, "Technology of materials and transport", e-mail: hardikov1990@mail.ru
}

\author{
${ }^{1}$ South-West State University, Kursk, Russia
}

\begin{abstract}
This work solves the problem of saving expensive chrome. This problem is proposed to be solved by grinding their waste of corrosion-resistant steels and reusing them. One of the most promising and industrially non-applicable methods for grinding any electrically conductive material is the electroerosion method. Comprehensive theoretical and experimental research is required to develop technologies for the reuse of electroerosive powders and evaluate the effectiveness of their use. The purpose of this work was to study the structure and properties of sintered samples from electroerosive corrosionresistant powders obtained in butyl alcohol.

To perform the planned studies, Kh13 steel waste was selected as the dispersible material. Waste steel Kh13 was processed at a voltage on the electrodes of 100-110 V; the capacity of the discharge capacitors is 45 UF and the pulse repetition rate is $65-75 \mathrm{~Hz}$. Butyl alcohol was used as the working fluid. The resulting powder was consolidated by spark plasma sintering (SPS) using the SPS 25-10 spark plasma sintering system.

Based on the conducted experimental studies aimed at studying the structure and properties of sintered samples from electroerosive corrosion-resistant powders obtained in butyl alcohol, the high efficiency of the spark plasma sintering technology is shown, which provides a uniform heat distribution over the sample, controlled porosity and high physical and mechanical properties with a short working cycle time and grain growth suppression.

Key words: corrosion-resistant steels, electroerosive dispersion, powder, spark plasma sintering, sintered product, properties.
\end{abstract}

DOI: $10.17580 /$ cisisr.2021.02.16

\section{Introduction}

Corrosion-resistant steels are characterized by several very valuable properties, thereby they are effectively used in different industries [1-3].

The sintering technology of corrosion-resistant steels has several features which are stipulated by high chromium affinity to oxygen and, respectively, by necessity of use of deeply dried protective media and high temperatures. Single and dual extrusion and sintering within the temperature range $1150-1300{ }^{\circ} \mathrm{C}$ are the most frequently applied technological procedures for manufacture of powder corrosion-resistant steels [4-8]. The properties of powder corrosion-resistant steels are generally determined by their porosity, thereby corrosion-resistant steels which are applied at present time are characterized by lower strength (by $10-30 \%$ ), plasticity (by $2-3$ times) and impact toughness in comparison with the corresponding properties of cast steels. It restricts their application area. Porosity of corrosion-resistant steels has negative effect on corrosion resistance. This problem can be solved owing to use of the spark plasma sintering technology which allows to decrease porosity in sintered alloys to $1 \%$ [9-14].

Additionally, presence of large amount of expensive chromium in corrosion-resistant steels is considered as one of the main problems of their recycling [15-17]. This problem can be solved via comminution of wastes and their secondary use. The existing industrial comminution technologies are characterized by large-scale production facilities, high energy consumption and environmental problems. So, electroerosion method seems to be one of the prospective and not applied industrially technologies for comminution of any conductive material at present time $[18,19]$.

At present time there are no scientific-technical developments for use of waste particles of corrosion-resistant alloys (which were dispersed by electroerosion) as charge material for manufacture of sintered products from these wastes. Conduction of complex theoretical and experimental investigations is required for these purposes. It will help to solve the problem of porosity decrease for sintered corrosion-resistant alloys and saving the expensive chromium.

The aim of this research was examination of structure and properties of sintered samples produced in butyl alcohol and fabricated from corrosion-resistant powders subjected to electroerosion.

Obtaining of the new relationships and interactions between composition, structure and properties of sintered corrosion-resistant alloys (from one side) and sintering technology for powder materials fabricated via electric dispersion of $12 \mathrm{Kh} 13$ steel wastes are estimated as novelty of this research.

To solve the above-noted problem of obtaining low-cost porous-free microstructure of corrosion-resistant steels, the prospective technologies of electroerosion dispersion and spark plasma sintering will be applied. 


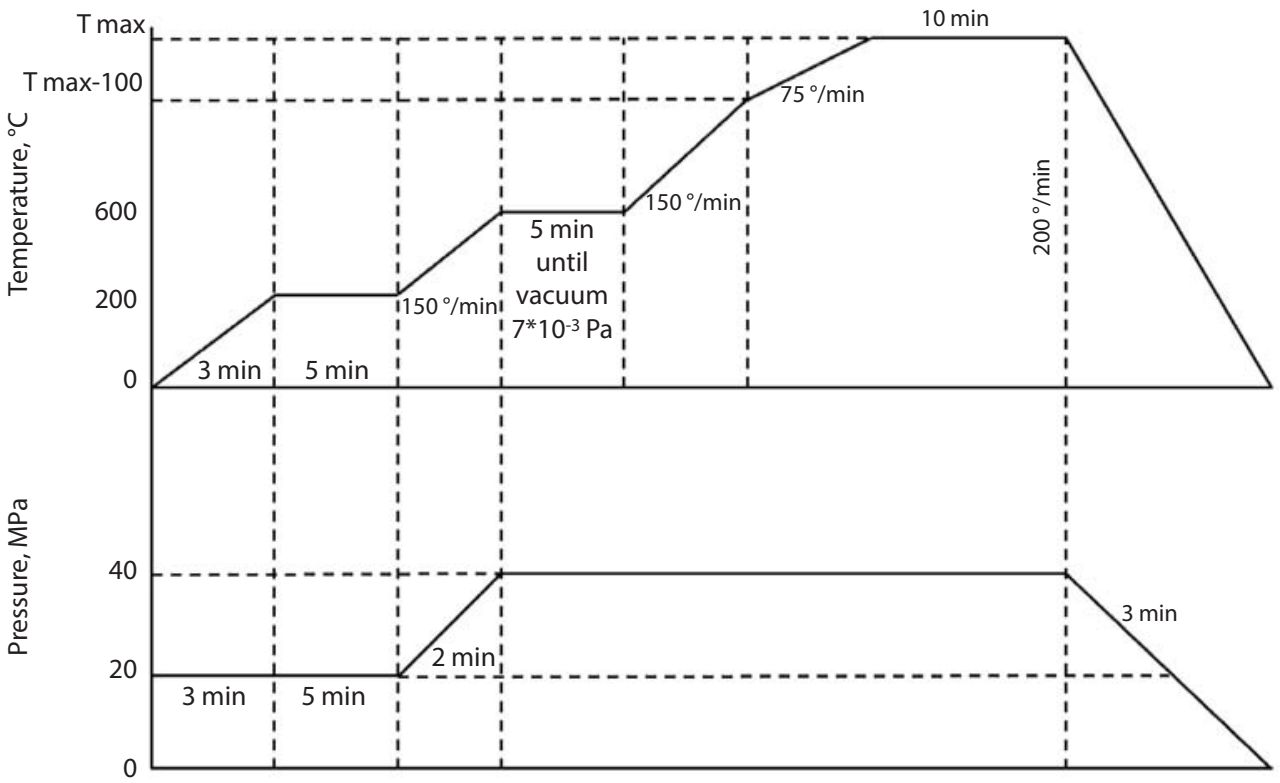

Fig. 1. Scheme of SPS powder consolidation

\section{Methods and materials}

$12 \mathrm{Kh} 13$ steel wastes were selected for conduction of planned researches as dispersed material; these wastes are accumulated at the enterprises in large amounts. $12 \mathrm{Kh} 13$ steel wastes, presented by tube cutting ends with size $30 \times 30 \times 20 \mathrm{~mm}$, were processed at the original unit for electric dispersion of current conducting wastes. Electric dispersion process was conducted with the following conditions: electrode voltage 100-110 V, capacity of discharge condensers $45 \mu \mathrm{F}$, pulse repetition frequency $65-75 \mathrm{~Hz}$. These conditions provide average particle size about $32.6 \mu \mathrm{m}$, they were obtained via the complete factorial experiment 23 , where electric dispersion procedures were chosen as factors.

Phase composition of $12 \mathrm{Kh} 13$ steel wastes before and after processing is presented in the Table 1. Elementary composition of these wastes did not vary essentially before and after processing and includes $\mathrm{Fe}, \mathrm{Cr}$ and $\mathrm{C}$.

Consolidation of obtained powder was carried out via the method of spark plasma sintering (SPS) using the corresponding system SPS 25-10 (Thermal Technology, USA) according to the scheme on the Fig. 1.

The results of initial researches displayed influence of technological parameters of plasma spark processing (temperature $\mathrm{T},{ }^{\circ} \mathrm{C}$; pressure $\mathrm{P}, \mathrm{MPa}$; holding time $\mathrm{t}$, min) on composition, structure and properties of obtained steel. The properties, which limit steel resource, provide technologically quick and comprehensive hardness determination, thereby optimization of steel production via spark sintering process of electroerosive charge material was conducted by the complete factorial experiment. Optimization was realized via pilot definition of such combination of levels of the factors, when maximal value of the finishing parameter can be achieved. The Box and Wilson path-of-steepest-ascent method was used in this case. Temperature, pressure and holding time were chosen as the factors. The ultimate values of optimization parameter $\hat{y}$ (hardness) for sintering were determined during experiments; it made 39.2 HRC for pressure $40 \mathrm{MPa}$, temperature $1250{ }^{\circ} \mathrm{C}$ and holding time $10 \mathrm{~min}$.

Initial material was placed in graphite matrix under the press in the vacuum chamber. Electrodes were integrated in the press mechanical part and conduct electric current to the matrix; so they create spark discharges between sintered material particles and provide intensive interaction.

Mechanical processing of sintered samples was conducted at automatic high-precision bench cutting machine "Accutom-5" and grinding and polishing machine "LaboPol-5".

Study of sintered sample microstructure was carried out along its surface via the method of scanning electron microscopy (microscope "Quanta 600 FEG”).

The spectra of typical X-ray radiation in different points on sample surface and its transversal polished specimen were obtained using energy-dispersion analyzer of EDAX X-ray radiation which is mounted in the scanning electron microscope "Quanta 600 FEG".

Porosity was determined using optical inverted microscope "Olympus GX51" with software for quantitative image analysis. Prepared samples have no traces of grinding, polishing or crumbling of structural components.

The sample microhardness along its surface was tested using automatic microhardness analytical system DM-8.

\begin{tabular}{|c|c|c|c|c|}
\hline \multicolumn{5}{|c|}{$\begin{array}{l}\text { Table 1. Phase composition of } 12 \mathrm{Kh} 13 \text { steel wastes before } \\
\text { and after processing }\end{array}$} \\
\hline \multirow{4}{*}{$\begin{array}{l}\text { Before } \\
\text { processing }\end{array}$} & \multirow{2}{*}{ Parameter } & \multicolumn{3}{|c|}{ Phase title } \\
\hline & & $\mathrm{Fe}$ & $\mathrm{Fe}_{3} \mathrm{C}$ & $\mathrm{Cr}$ \\
\hline & $\begin{array}{c}\text { Crystal } \\
\text { lattice type }\end{array}$ & $\begin{array}{l}\text { Cubic } \\
\text { crystal } \\
\text { lattice }\end{array}$ & $\begin{array}{l}\text { Orthorhombic } \\
\text { crustal lattice }\end{array}$ & $\begin{array}{l}\text { Cubic } \\
\text { crystal } \\
\text { lattice }\end{array}$ \\
\hline & $\begin{array}{c}\text { Parameters } \\
\text { of crystal } \\
\text { lattice, } \AA\end{array}$ & $\begin{array}{l}a=b=c= \\
3.615426\end{array}$ & $\begin{array}{c}a=0.462718 \\
b=0.534642 \\
c=0.680872\end{array}$ & $\begin{array}{l}a=b=c= \\
4.568742\end{array}$ \\
\hline \multirow{3}{*}{$\begin{array}{c}\text { After } \\
\text { processing }\end{array}$} & Parameter & $\mathrm{Cr}$ & $\mathrm{Cl}_{7}$ & \\
\hline & $\begin{array}{c}\text { Crystal } \\
\text { lattice type }\end{array}$ & $\begin{array}{l}\text { Cubic } \\
\text { crystal } \\
\text { lattice }\end{array}$ & $\begin{array}{l}\text { Orthorhombic } \\
\text { crustal lattice }\end{array}$ & $\begin{array}{l}\text { Cubic } \\
\text { crystal } \\
\text { lattice }\end{array}$ \\
\hline & $\begin{array}{c}\text { Parameters } \\
\text { of crystal } \\
\text { lattice, } \AA\end{array}$ & $\begin{array}{l}a=b=c= \\
4.571221\end{array}$ & $\begin{array}{c}a=6.940538 \\
b=12.029685 \\
c=4.506928\end{array}$ & $\begin{array}{l}a=b=c= \\
3.605153\end{array}$ \\
\hline
\end{tabular}




\section{Results of investigations}

Microstructure of the sample (along its surface and transversal polished section) was examined via scanning electron microscopy. Surface of a polished section was subjected to grinding and polishing. Grinding was conducted using metallographic paper with coarse (No. 60-70) and fine (No. 220-240) grain. The sample was periodically turned by $90^{\circ}$ during grinding. Abrasive particles were washed by water and then the sample was polished using buff wheel with suspensions of metal oxides $\left(\mathrm{Fe}_{3} \mathrm{O}_{4}, \mathrm{Cr}_{2} \mathrm{O}_{3}, \mathrm{Al}_{2} \mathrm{O}_{3}\right)$. When achieving a mirror gloss, polished section surface was washed by water and alcohol, then dried by filtering paper. The spectra of typical X-ray radiation in different points of sample surface and transversal polished section were obtained using EDAX energy-dispersion analyzer which is mounted in the scanning electron microscope "Quanta 600 FEG".

Generalized data on the results of examination of microstructure and X-ray spectral microanalysis (XSMA) for sintered samples made of electroerosion corrosion-resistant powders, manufactured in kerosene, are presented on the Fig. 2. A peak of definite height corresponds to each element on the spectra.

It was established experimentally that carbon part is presented in the sintered samples made of electroerosion corrosion-resistant powders and manufactured in kerosene, while all other elements are distributed relatively homoge-
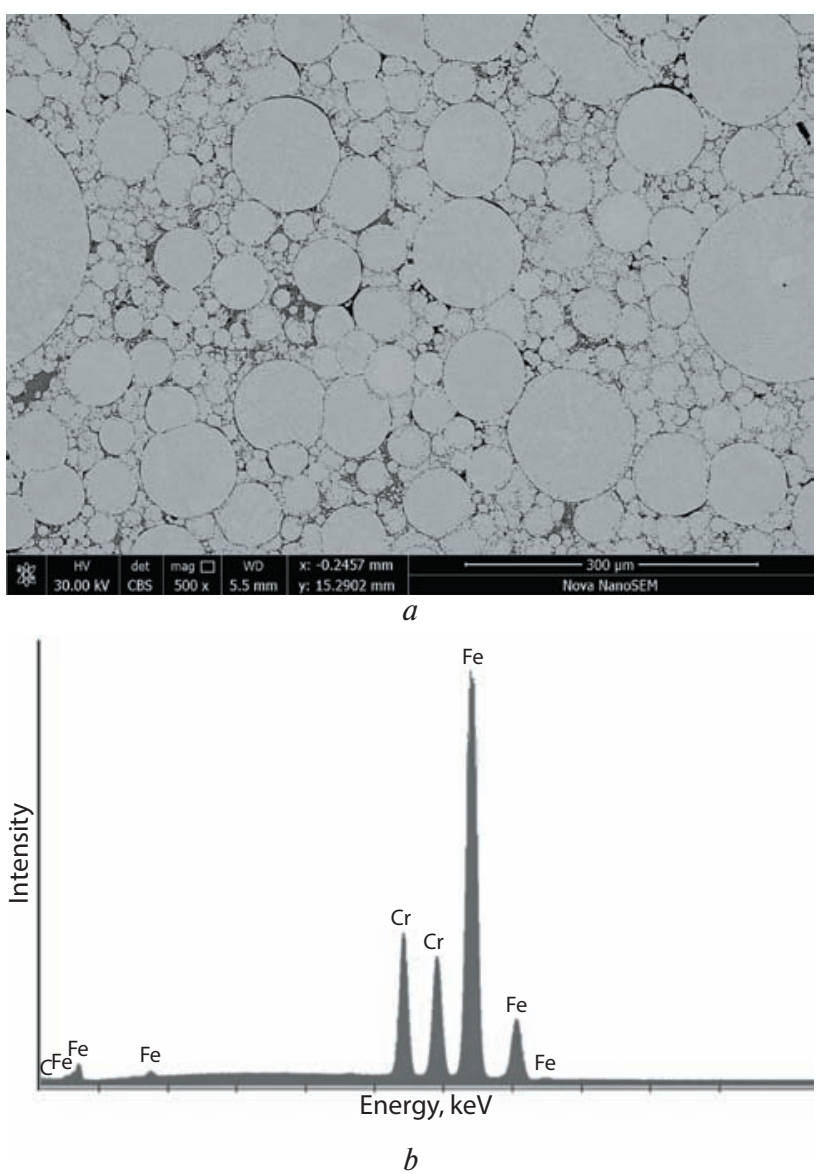

Fig. 2. Sintered sample: $a-$ microstructure; $b$ - elementary composition neously through the volume. It is shown that $\mathrm{Fe}, \mathrm{Cr}$ and $\mathrm{C}$ are the main elements in the alloys.

The results of examination of X-ray structural (phase) composition of sintered samples are presented on the Fig. 3 and in the Table 2.

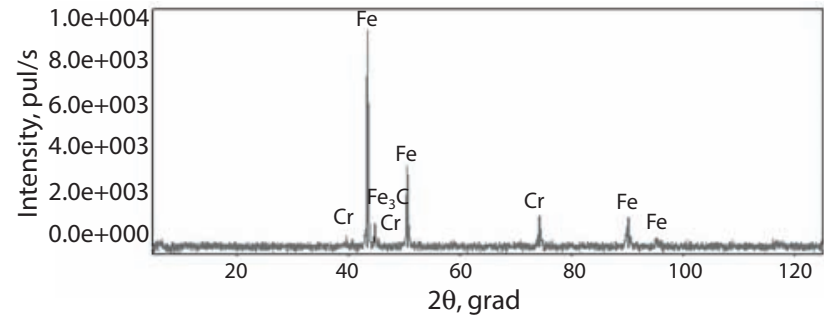

Fig. 3. Diffraction pattern of sintered samples

\begin{tabular}{|c|c|c|c|}
\hline \multicolumn{4}{|c|}{ Table 2. Phase composition of sintered samples } \\
\hline \multirow{2}{*}{ Parameter } & \multicolumn{3}{|c|}{ Phase title } \\
\hline & $\mathrm{Fe}$ & $\mathrm{Fe}_{3} \mathrm{C}$ & $\mathrm{Cr}$ \\
\hline $\begin{array}{l}\text { Type of crystal } \\
\text { lattice }\end{array}$ & $\begin{array}{c}\text { Cube crystal } \\
\text { lattice }\end{array}$ & $\begin{array}{l}\text { Orthorhombic } \\
\text { crystal lattice }\end{array}$ & $\begin{array}{l}\text { Cube crystal } \\
\text { lattice }\end{array}$ \\
\hline $\begin{array}{l}\text { Parameters of } \\
\text { crystal lattice, } \AA\end{array}$ & $\begin{array}{l}a=b=c= \\
3.609732\end{array}$ & $\begin{array}{l}a=0.452431 \\
b=0.508855 \\
c=0.674315\end{array}$ & $\begin{array}{l}a=b=c= \\
4.531833\end{array}$ \\
\hline
\end{tabular}
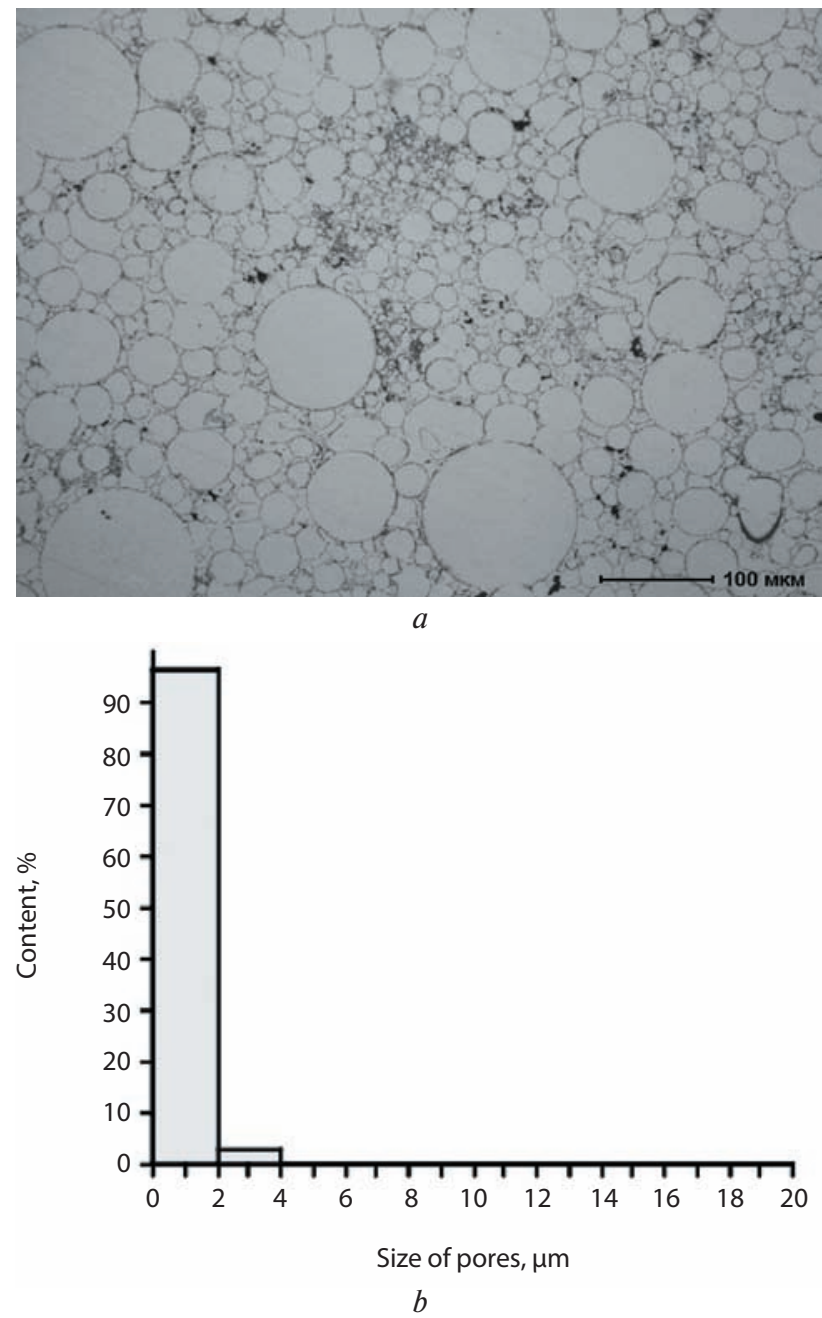

Fig. 4. Results of porosity examination: $a-$ microstructure of transversal polished section of the sample; $b$ - histogram of pores distribution according to their diameter 
It was established experimentally that $\mathrm{Fe}, \mathrm{Cr}$ and $\mathrm{Fe}_{3} \mathrm{C}$ are the main phases in the sintered samples made from electroerosion corrosion-resistant powders and obtained in butyl alcohol.

Porosity of sintered samples was determined via metallographic method using the elements of qualitative and quantitative analysis of pores geometry (stereoscopic metallography). Use of this method allowed to calculate specific surface of large pores, number of spherical pores in volume unit, average distance between pores, average real diameter of spherical pores etc. The results of examination of samples porosity via metallographic method using optical microscope OLYMPUS GX51 are presented on the Fig. 4.

It was found out on the base of porosity examination of sintered samples via metallographic method that its value makes about $0.34 \%$.

It was established experimentally that microhardness of sintered samples, manufactured via the method of spark plasma sintering from electroerosion dispersed particles of Kh13 alloy, makes $461 \mathrm{HV}_{0.2}$ (dispersion made 300.67 and relative error $-2.18 \%$ ).

The scientific and applied principles of conjugation of the technology for manufacture of new powder materials from corrosion-resistant steel $12 \mathrm{Kh} 13$ wastes via electroerosion dispersion and the technology of compacting these powders via spark plasma sintering are realized in this research.

\section{Conclusions}

1. Influence of the spark plasma sintering technology on physical-chemical properties (such as porosity and microhardness) of powder corrosion-resistant steel is shown on the base of conducted experimental investigations. It is noted that this technology provides uniform heat distribution along a sample, controlled porosity and microhardness high physical-mechanical properties during short time of a work cycle and grain growth inhibition.

2. It was noted that corrosion-resistant alloys from electroerosion dispersed particles of 12Rh13 alloy, which were manufactured via spark plasma sintering, are characterized by the following parameters:

- equilibrium state with submicron and nano-scaled grain;

- $\mathrm{Fe}, \mathrm{Cr}$ and $\mathrm{C}$ as the main components of the alloys;

- main phases of $\mathrm{Fe}, \mathrm{Cr}$ and $\mathrm{Fe}_{3} \mathrm{C}$;

- microhardness $436 \mathrm{HV}_{0.2}$;

- porosity $0.34 \%$.

3. Developed sintered corrosion-resistant alloys with porous-free microstructure will allow in the prospect to expand the area of practical application of these steels together with cast steels. Use of corrosion-resistant powders obtained from wastes on the base of energy-saving electric dispersion technology for manufacture of sintered corrosion-resistant alloys will help to decrease by the order their production expenses.

The work was supported by a scholarship of the President of the Russian Federation for young scientists and graduate students (SP-945.2019.1)

\section{REFERENCES}

1. Gu H., Van Gelder A. Laser localized coating of corrosion resistant metal over a steel weld bead. Journal of Laser Applications. 2016. Vol. 28. No. 2. pp. 022411.

2. Trung P. H., Chigirinskiy J. L. Analyzing the mechanisms of cutting tool wear during the machining of corrosion-resistant steels. Materials Science Forum. 2019. Vol. 973. pp. 120-124.

3. Weber S., Mújica Roncery L., Theisen W. Mechanical properties of (20-30) $\mathrm{Mn} 12 \mathrm{Cr}(0.56-0.7) \mathrm{CN}$ corrosion resistant austenitic TWIP steels. Steel Research International. 2012. Vol. 83. No. 4. pp. 307-314.

4. Mujica L., Weber S., Hunold G., Theisen W. Development and characterization of novel corrosion-resistant TWIP steels. Steel Research International. 2011. Vol. 82. No. 1. pp. 26-31.

5. Huth S., Krasokha N., Theisen W. Development of wear and corrosion resistant cold-work tool steels produced by diffusion alloying. Wear. 2009. T. 267. No. pp. 449-457.

6. Kaneko M. Role of low alloy corrosion resistant steels toward realization of a sustainable society. Corrosion Engineering. 2014. Vol. 63. No. 4. pp. 126.

7. Travyanov A. Ya., Dub A. V., Petrovskiy P. V., Cheverikin V. V. Study of mechanical properties of cellular structures from $03 \mathrm{Kh}-$ $16 \mathrm{~N} 15 \mathrm{M} 3$ stainless steel depending on parameters of an elementary cell. Chernye metally. 2018. No. 10. pp. 59-63.

8. Gots A. N., Lyukhter A. B., Gusev D. S., Zavitkov A. V. Selection of modes for laser cladding of PR-08Kh17N8S6G powder. Chernye metally. 2020. No. 11. pp. 46-51.

9. Grigorovich K. V., Komolova O. A., Rumyantsev B. A. Study of sulfur effect on the processes of plasma decarbonization and desulfurization of corrosion-resistant steels. Metally. 2019. No. 6 . pp. $34-40$.

10. Khamin O. N., Kadyamov Sh. A. Comparative analysis of the methods of surface strengthening of corrosion-resistant steels of austenite class. Sovremennye materialy. 2020. No. 5 (32). pp. $120-128$.

11. Pridein A. A., Bazaev E. L., Zubov S. P., Kormishin A. M., Bedrinov A. I. Mastering of production of corrosion-resistant rolled sheets for a field pipelines made of $13 \mathrm{KhFA}$ steels with increased cold resistance. Proizvodstvo prokata. 2018. No. 3. pp. 28-36.

12. Smetkin A. A., Oglezneva S. A., Kalinin K. V., Lhanipov E. F. Structure and properties of corrosion-resistant steel manufactured via selective laser melting. Izvestiya vysshikh uchebnykh zavedeniy. Poroshkovaya metallurgiya i funktsionalnye pokrytiya. 2019. No. 1. pp. 91-97.

13. Lobanov M. L., Pastukhov V. I., Redikultsev A. A. Crystallographic features of $\gamma$-phase decomposition in austenite corrosionresistant steel. Metallovedenie i termicheskaya obrabotka metallov. 2020. No. 7 (781). pp. 5-11.

14. Bakradze M. M., Voznesenskaya N. M., Leonov A. V., Krylov S. A., Tonysheva O. A. Development and investigation of high-strength corrosion-resistant steel for bearings components. Metallurg. 2019. No. 11. pp. 39-44.

15. Ryabova A. V., Yatsenko E. A., KhoroshavinaV. V., Klimova L.V. Glass-enamel corrosion-resistant coatings for steel pipelines. Glass and Ceramics. 2017. Vol. 74. No. 7-8. pp. 282-287.

16. Ratkevich G. V., Afanasyeva L. E., Zhdanov A. V., Belyaev L. V., Yugov V. I. Selective laser melting of corrosion-resistant steel. Russian metallurgy (Metally). 2019. No. 13. pp. 1433-1437.

17. Panfilova L. M., Smirnov L. A., Yakovleva I. L., Tereshchenko N. A. Development of high-strength corrosion-resistant steel for submersible centrifugal electric pump shafts. Metallurgist. 2017. Vol. 60. No. 11-12. pp. 1250-1255.

18. Latypov R. A., Latypova G. R., Ageev E. V., Altukhov A. Y., Ageeva E. V. Elemental composition of the powder particles produced by electric discharge dispersion of the wastes of a VK8 hard alloy. Russian metallurgy (Metally). 2017. No. 12. pp. 1083-1085.

19. Latypov R. A., Latypova G. R., Ageev E. V., Altukhov A. Y., Ageeva E. V. Properties of the coatings fabricated by plasma-jet hard-facing by dispersed mechanical engineering wastes. Russian metallurgy (Metally). 2018. No. 6. pp. 573-575. 